\begin{tabular}{ll}
\hline JURNAL PELITA PENDIDIKAN & $\begin{array}{l}\text { Volume } 7 \text { Nomor } 1 \text { (2019) } 009 \text { - } 015 \\
\text { Jurnal Pelita Pendidikan } \\
\text { Journal of Biology Education } \\
\text { https://jurnal.unimed.ac.id/2012/index.php/pelita/index }\end{array}$ \\
\hline
\end{tabular}

\title{
ANALISIS KUANTITAS DAN KUALITAS PERTANYAAN GURU BIOLOGI DAN SISWA PADA MATERI SISTEM EKSKRESI
}

\author{
Aldenan Samosir ${ }^{1 *}$, Hasruddin ${ }^{1}$, Herawati Dongoran ${ }^{2}$

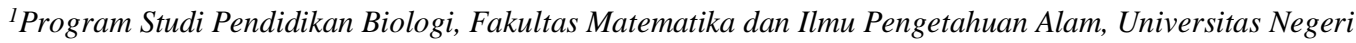 \\ Medan, Jalan Willem Iskandar Pasar V Medan Estate 20221, Sumatera Utara, Indonesia \\ ${ }^{2}$ Guru Biologi MAN 1 Medan, Jalan SWillem Iskandar, Medan, Kode Pos 20221 \\ Korespondensi Author: aldenansamosir@gmail.com (Samosir)
}

\section{INFO ARTIKEL}

\section{Histori Artikel}

Received 24 Agustus 2018

Revised 22 Maret 2019

Accepted 3 April 2019

Published 7 Juli 2019

Keywords:

Student question, teacher question, excretion system

\begin{abstract}
This study aims to determine the quantity and quality of biology teacher questions and students during the excretory system learning at MAN 1 Medan in the year of 2017/2018 learning. This type of research is descriptive survey research. The population of this research is biology teacher class XI MIA and all students of class XI MIA. Samples were taken by purposive sampling technique by taking 3 of the most active classes with different biology teachers. Data collection techniques are by direct observation during learning. The results show that all teachers submit oral and written questions totaling 59 questions. Oral biology teacher questions $81 \%$ and writing questions $19 \%$. The quality of teacher questions is more HOTS quality than LOTS. Different results are indicated by the questions posed by students, with a total of 520 questions. More writing questions than oral questions. Student questions verbally by $23 \%$ and writing questions by $77 \%$.
\end{abstract}

How to Cite:

Samosir, A., Hasruddin, Dongoran, H. (2019) Analisis Kuantitas dan Kualitas Pertanyaan Guru Biologi dan Siswa Materi Sistem Ekskresi. Jurnal Pelita Pendidikan, 7(1), 009-015.

\section{PENDAHULUAN}

Proses belajar mengajar merupakan gabungan dua konsep yaitu belajar yang dilakukan oleh siswa dan mengajar yang dilakukan oleh guru. Belajar tertuju oleh apa yang harus dilakukan oleh seseorang sebagai subjek yang menerima pelajaran, sedangkan mengajar tertuju pada apa yang harus dilakukan oleh guru sebagai pemberi pelajaran. Dua konsep tersebut menjadi terpadu pada suatu kegiatan pada saat terjadi interaksi antara guru dan siswa (Yani dan Bagja, 2007).

Mengajar pada hakekatnya adalah suatu proses, yakni proses mengatur, mengorganisasi lingkungan yang ada di sekitar siswa sehingga dapat menumbuhkan dan mendorong siswa melakukan proses belajar mengajar (Sudjana, 1989). Keterampilan mengajar merupakan kegiatan yang dilakukan oleh guru dalam kegiatan pembelajaran untuk menciptakan kondisi belajar murid agar minat dan perhatiannya terpusat pada apa yang akan dipelajarinya (Saud, 2011)

Kalau siswa mendengarkan ceramah terus menerus, maka akan mengantuk dan bosan. Lama kelamaan perhatiannya menurun, apalagi bila suara dan ucapan kata-kata guru tidak menarik. Maka untuk menciptakan kehidupan interaksi belajar mengajar perlu guru 
menimbulkan teknik tanya jawab atau dialog, ialah suatu teknik untuk memberi motivasi pada siswa agar bangkit pemikirannya untuk bertanya, selama mendengarkan pembelajaran atau guru yang mengajukan pertanyaanpertanyaan itu (Roestiyah, 2012).

Keterampilan bertanya sangat penting dimiliki seorang guru, karena dapat membangkitkan minat dan rasa ingin tahu siswa, memusatkan perhatian siswa terhadap pokok bahasan atau konsep yang diajarkan dan mengembangkan cara belajar aktif peserta didik (Simamora, 2014). Dengan adanya pertanyaan dari guru, maka siswa akan berpikir untuk menjawab pertanyaan tersebut. Guru akan mengetahui tingkat berpikir kritis siswa melalui jawaban siswa. Jumlah dan kualitas pertanyaaan yang diajukan peserta didik dapat digunakan untuk mengukur keterampilan berpikir kritis (Mahanal dkk, 2007).Pertanyaan yang diajukan guru kepada siswa merupakan bagian penting dalam pengembangan kemampuan berpikir kritis siswa (Hasruddin, 2011).

Keterampilan bertanya, bagi seseorang siswa merupakan keterampilan yang sangat penting untuk dikuasai, sebab melalui keterampilan ini siswa dapat menciptakan suasana pembelajaran lebih bermakna. Dapat anda rasakan, pembelajaran akan menjadi sangat membosankan, manakala selama berjam-jam guru menjelaskan materi pelajaran tanpa diselingi dengan pertanyaan, baik sekedar pertanyaan pancingan, atau pertanyaan untuk mengajak siswa berpikir. Oleh karena itu dalam setiap proses pembelajaran, model pembelajaran apapun yang digunakan bertanya merupakan kegiatan yang selalu merupakan bagian yang tidak dapat dipisahkan (Sanjaya, 2005).

Untuk mengukur kemampuan bertanya dapat dilakukan dengan cara melihat frekuensi yang bertanya serta kualitas pertanyaannya (Mahanal dkk, 2007). Kualitas pertanyaan dapat dibedakan berdasarkan kualitas pertanyaan yang mengarah ke Lower Order ThinkingSkills (LOTS) atau Higher OrderThinking Skills (HOTS) yang mengacu pada taksonomi Bloom Kualitas pertanyaan tergolong lower order thinking skills (LOTS) menunjukkanmasih rendahnya cara berpikir peserta didik(Rosyida dkk,2016).
Pertanyaan dikatakan HOTS jika sudah mengarah ke analisis (Ramadhan dkk, 2017).

Pentingnya pertanyaan selama pembelajaran mendorong penulis untuk mengetahui kuantitas dan kualitas pertanyaan guru biologi dan siswa selama proses pembelajaran materi sistem ekskresi.

\section{METODE PENELITIAN}

Penelitian dilakukan pada bulan Februari-Mei 2018 di MAN 1 Medan.Populasi pada penelitian ini adalah seluruh guru biologi dan siswa kelas XI MIA yang terdiri 3 guru biologi dari 8 kelas di Man 1 Medan T.P 2017/1018. Penentuan sampel dilakukan dengan teknik Purposive Sampling. Kelas yang digunakan sebagai Sampel pada penelitian ini berjumlah 3 kelas dengan guru biologi yang berbeda, yaitu kelas MIA 5, MIA 7 dan MIA 8 yang berjumlah 123 siswa.

Jenis penelitian yang digunakan dalam penelitian ini adalah deskriptif survei. Teknik pengumpulan data pada penelitian ini adalah observasi. Data yang diperoleh didapatkan dari pengamatan selama proses pembelajaran berlangsung di dalam kelas pada materi sistem ekskresi. Setelah penulis mengumpulkan data, selanjutnya penulis menghitung jumlah pertanyaan guru dan jumlah pertanyaan siswa selama proses pembelajaran berlangsung. Kemudian pertanyaaan dikategorikan berdasarkan taksonomi Bloom revisi Anderson dan Krathwall. Analisis dilakukan dengan mencocokkan pertanyaan ke dalam taksonomi Bloom revisi Anderson dan Krathwall, yaitu mengingat $\left(C_{1}\right)$, memahami $\left(C_{2}\right)$, menerapkan $\left(C_{3}\right)$, menganalisis $\left(C_{4}\right)$, mengevaluasi $\left(C_{5}\right)$, dan mengkreasi $\left(C_{6}\right)$. Setelah kategorisasi, data akan divalidasi oleh orang yang ahli dalam bidangnya, kemudian dikelompokkan ke dalam Lower Order ThinkingSkills (LOTS) atau Higher OrderThinking Skills (HOTS).

\section{HASIL DAN PEMBAHASAN}

Jumlah pertanyaan guru secara lisan maupun tulisan secara keseluruhan dalam empat kali pertemuan yang sesuai dengan materi sistem ekskresi dapat dilihat pada Tabel 1.

Tabel 1. Persentase Jumlah Pertanyaan Guru Lisan dan Tulisan Secara Keseluruhan 


\begin{tabular}{|c|c|c|c|c|c|c|c|}
\hline \multirow{3}{*}{ No } & \multirow{3}{*}{ Aspek } & \multicolumn{6}{|c|}{ Kelas } \\
\hline & & \multicolumn{2}{|c|}{ MIA 5} & \multicolumn{2}{|c|}{ MIA 7} & \multicolumn{2}{|c|}{ MIA 8} \\
\hline & & Lisan & Tulisan & Lisan & Tulisan & Lisan & Tulisan \\
\hline 1 & $\begin{array}{l}\text { Metode } \\
\text { Pembelajaran }\end{array}$ & \multicolumn{2}{|c|}{ Diskusi } & \multicolumn{2}{|c|}{ Diskusi } & \multicolumn{2}{|c|}{ Diskusi } \\
\hline 2 & $\begin{array}{l}\text { Jumlah } \\
\text { Pertanyaan }\end{array}$ & 10 & 3 & 17 & 4 & 21 & 4 \\
\hline 3 & $\begin{array}{l}\text { \% Jumlah } \\
\text { Pertanyaan } \\
\text { Guru }\end{array}$ & $17 \%$ & $5 \%$ & $29 \%$ & $7 \%$ & $35 \%$ & $7 \%$ \\
\hline
\end{tabular}

Tabel 1 menunjukkan jumlah seluruh pertanyaan guru selama empat kali pertemuan adalah 59 pertanyaan. Pertanyaan secara lisan paling banyak terdapat di kelas MIA 8 dengan persentase $35 \%$.
Jumlah pertanyaan siswa secara lisan maupun tulisan secara keseluruhan didistribusikan ke dalam empat kali pertemuan yang sesuai dengan materi dapat dilihat pada Tabel 2.

Tabel 2. Distribusi Persentase Jumlah Pertanyaan Siswa dalam Empat Kali Pertemuan

\begin{tabular}{|c|c|c|c|c|c|c|}
\hline Kelas & Pertemuan & $\begin{array}{c}\text { Metode } \\
\text { Pembelajaran }\end{array}$ & $\begin{array}{c}\text { Jenis } \\
\text { Pertanyaan }\end{array}$ & $\begin{array}{c}\text { Jumlah } \\
\text { Pertanyaan }\end{array}$ & $\begin{array}{c}\text { Jumlah } \\
\text { siswa } \\
\text { Hadir }\end{array}$ & $\begin{array}{c}\text { Persentase } \\
\text { Jumlah } \\
\text { pertanyaan }\end{array}$ \\
\hline \multirow{5}{*}{ MIA 5} & $\mathrm{I}$ & Diskusi & Lisan & 10 & 44 & $2 \%$ \\
\hline & II & Diskusi & Lisan & 8 & 42 & $1,5 \%$ \\
\hline & III & Diskusi & Lisan & 7 & 43 & $1,3 \%$ \\
\hline & IV & & Lisan & 17 & \multirow{2}{*}{42} & $3,3 \%$ \\
\hline & IV & DISKUSI & Tulisan & 151 & & $29 \%$ \\
\hline \multirow{5}{*}{ MIA 7} & $\mathrm{I}$ & Diskusi & Lisan & 10 & 41 & $2 \%$ \\
\hline & II & Diskusi & Lisan & 9 & 42 & $1,7 \%$ \\
\hline & III & Diskusi & Lisan & 7 & 40 & $1,3 \%$ \\
\hline & \multirow{2}{*}{ IV } & \multirow{2}{*}{ Diskusi } & Lisan & 9 & \multirow{2}{*}{38} & $1,7 \%$ \\
\hline & & & Tulisan & 135 & & $26 \%$ \\
\hline \multirow{5}{*}{ MIA 8} & I & Diskusi & Lisan & 12 & 36 & $2,3 \%$ \\
\hline & II & Diskusi & Lisan & 11 & 36 & $2,1 \%$ \\
\hline & III & Diskusi & Lisan & 8 & 33 & $1,5 \%$ \\
\hline & \multirow{2}{*}{ IV } & \multirow{2}{*}{ Diskusi } & Lisan & 12 & \multirow{2}{*}{34} & $2,3 \%$ \\
\hline & & & Tulisan & 114 & & $22 \%$ \\
\hline
\end{tabular}

Tabel 2 menunjukkan bahwa jumlah pertanyaan seluruh siswa selama empat kali pertemuan adalah 520 pertanyaan. Pertanyaan secara lisan paling banyak adalah di kelas MIA 8 yaitu sebanyak 12 pertanyaan pada pertemuan I dan IV, sedangkan pertanyaan tulisan paling banyak adalah di kelas MIA 5 dengan 151 pertanyaan. Hasil kategorisasi dan kualitas pertanyaan guru secara keseluruhan disajikan dalam bentuk Tabel 3 .

Tabel 3 Kategorisasi dan Kualitas Pertanyaan Guru Secara Keseluruhan

\begin{tabular}{|c|c|c|c|}
\hline Kualitas & Kategori & Jumlah Pertanyaan & Persentase \\
\hline & $\mathrm{C}_{1}$ & 6 & $10 \%$ \\
\hline \multirow[t]{2}{*}{ LOTS } & $\mathrm{C}_{2}$ & 17 & $29 \%$ \\
\hline & $\mathrm{C}_{3}$ & 6 & $10 \%$ \\
\hline \multicolumn{2}{|c|}{ Jumlah } & 29 & $49 \%$ \\
\hline \multirow{3}{*}{ HOTS } & $\mathrm{C}_{4}$ & 30 & $51 \%$ \\
\hline & $\mathrm{C}_{5}$ & 0 & $0 \%$ \\
\hline & $\mathrm{C}_{6}$ & 0 & $0 \%$ \\
\hline \multicolumn{2}{|c|}{ Jumlah } & 30 & $51 \%$ \\
\hline
\end{tabular}


Dari tabel 3 dapat dilihat bahwa Sekitar 49\% pertanyaan guru tergolong dalam Lower Order Thinking Skill (LOTS) dan 51\% tergolong
Higher Order Thingking Skill (HOTS). Hasil kategorisasi pertanyaan siswa secara keseluruhan disajikan dalam Tabel 4.

Tabel 4 Kategori dan Kualitas Pertanyaan Siswa Secara Keseluruhan

\begin{tabular}{|c|c|c|c|}
\hline \multirow[t]{2}{*}{ Kualitas } & Kategori & Jumlah Pertanyaan & Persentase \\
\hline & $\mathrm{C}_{1}$ & 132 & $25 \%$ \\
\hline \multirow[t]{2}{*}{ LOTS } & $\mathrm{C}_{2}$ & 201 & $39 \%$ \\
\hline & $\mathrm{C}_{3}$ & 25 & $5 \%$ \\
\hline \multicolumn{2}{|c|}{ Jumlah } & 358 & $69 \%$ \\
\hline \multirow{3}{*}{ HOTS } & $\mathrm{C}_{4}$ & 162 & $31 \%$ \\
\hline & $\mathrm{C}_{5}$ & 0 & $0 \%$ \\
\hline & $\mathrm{C}_{6}$ & 0 & $0 \%$ \\
\hline \multicolumn{2}{|c|}{ Jumlah } & 162 & $31 \%$ \\
\hline
\end{tabular}

Tabel 4 menunjukkan kategori pertanyaan siswa secara keseluruhan. Jumlah keseluruhan pertanyaan siswa sebanyak 520 pertanyaan. Sekitar 69\% pertanyaan siswa tergolong dalam Lower Order Thinking Skill (LOTS) dan 31\% tergolong Higher Order Thingking Skill (HOTS).

\section{Analisis Pertanyaan Berdasarkan Kuantitas Pertanyaan Guru dan siswa}

Jika dilihat dari jumlah siswa yang hadir, seluruh siswa ketiga kelas menyampaikan pertanyaan secara tulisan. Hal ini dapat terjadi karena adanya keterbatasan waktu yang tidak memungkinkan seluruh siswa dapat bertanya secara lisan selama proses pembelajaran. Selain itu faktor dalam diri siswa juga dapat mempengaruhi jumlah siswa yang bertanya. Adanya rasa kurang percaya diri siswa membuat siswa tidak bertanya.

kelas sudah menglui pengamatan penulis, ketiga pembelajaran diskusi, namun yang membedakannya adalah keterlibatan guru selama proses pembelajaran berlangsung. Guru kelas XI MIA 5 cenderung kurang terlibat dalam membimbing diskusi jika dibanding guru XI MIA 7 dan XI MIA 8 yang cenderung ikut serta memberikan pendapat selama diskusi berlangsung sehingga membuat siswa di kelas XI MIA 5 kurang berpartisipasasi dalam pembelajaran. Sedangkan dalam Hasibuan (2008) menyatakan bahwa keterampilan bertanya sangat penting dimiliki seorang guru, karena dapat meningkatkan partisipasi siswa dalam kegitan pembelajaran, membangkitkan minat dan rasa ingin tahu, mengembangkan pola berpikir dan cara belajar aktif, dan memusatkan perhatian siswa.
Tanaya dkk (2017) menyatakan bawa pembelajaran biologi yang didesain dan diterapkan dengan pendekatan saintifik akan merangsang siswa untuk meningkatkan rasa ingin tahu, hendaknya siswa dilibatkan pada pengalaman belajar langsung untuk menemukan konsep seperti layaknya ilmuan, rasa ingin tahu yang besarakan menimbulkan banyak pertanyaan dari siswa karena menemukan hal-hal baru yang belum diketahui oleh mereka sebelumnya.

Mengajukan pertanyaan merupakan aktivitas kunci dalam melaksanakan pembelajaran yang aktif dan bermakna. Pertanyaan menjadi indikator kemampuan berpikir peserta didik yang diketahui melalui kuantitas dan kualitas (Chin dan Osborne, 2008). Seorang guru tidak bisa hanya berdiri seraya berkata "apakah ada pertanyaan, ada yang ingin ditanyakan, ada yang kurang dimengerti", hal tersebut tentu saja membuat siswa merasa malu untuk mengajukan pertanyaan, kurang percaya diri, dan takut untuk bertanya, sehingga tidak dapat mendorong siswa untuk bertanya. Seharusnya seorang guru memberikan pertanyaan yang bersifat responsif kepada siswa untuk mengembangkan cara berpikir siswa (Bulgar, 2002).

Biddulph \& Osborne dalam Chin (2002) mengemukakan bahwa jumlah pertanyaan siswa akan dipengaruhi oleh umur, pengalaman, pengetahuan awal dan keterampilan, sikap guru, gaya mengajar, topik, recognisi, dan pola interaksi sosial. Siswa yang tidak biasa mengajukan pertanyaan akan merasa kesulitan dalam pembelajaran, dan siswa yang terbiasa menjawab pertanyaan akan lebih senang menjawab pertanyaan dari pada mengajukan pertanyaan (Tanaya, 2017). 
Analisis Kategori dan Kualitas Pertanyaan Guru dan Siswa Berdasarkan Taksonomi Bloom Revisi

Kualitas pertanyaan guru dan siswa dapat diukur dengan mengacu pada taksonomi Bloom (Smith dan Szymanski, 2013). Menurut taksonomi Bloom yang telah direvisi proses kognitif terbagi menjadi kemampuan berpikir tingkat rendah (Lower Order Thinking Skill) dan kemampuan berpikir tingkat tinggi (Higher Order Thinking Skill). Kemampuan yang termasuk LOTS adalah kemampuan mengingat (remember), memahami (understand), dan menerapkan (apply), sedangkan HOTS meliputi kemampuan menganalisis (analyze), mengevaluasi (evaluate), dan menciptakan (create) (Istiyono dkk, 2014).

Kategori pertanyaan guru dan siswa terdapat ke dalam kategori $\mathrm{C}_{1}-\mathrm{C}_{4}$ dan tidak terdapat kedalam kategori $\mathrm{C}_{5}-\mathrm{C}_{6}$. Secara keseluruhan pertanyaan guru yang paling sering muncul adalah pertanyaan kategori $\mathrm{C}_{4}$ (menganalisis). Kategori menganalisis merupakan kategori menguraikan suatu permasalahan dan menentukan bagaimana keterkaitan antara unsur-unsur tersebut (Widodo, 2006). Contoh pertanyaannya adalah, "Kita sering mendengar bahwa banyak minum air akan menyehatkan ginjal, tetapi justru orang yang menderita penyakit ginjal harus membatasi asupan jumlah air minum. Adakah hubungannya antara konsumsi jumlah air minum dengan kesehatan ginjal? Mengapa demikian?". Pertanyaan ini dapat membuat siswa untuk menggali informasi mengenai ginjal lebih mendalam.

Pertanyaan siswa secara keseluruhan yang paling sering muncul adalah pertanyaan katergori $\mathrm{C}_{2}$ (memahami). Memahami berkaitan dengan mengkonstruk makna atau pengertian berdasarkan pengetahuan awal yang dimiliki (Widodo, 2006). Contoh kategori pertanyaan siswa yang termasuk kedalam kategori $C_{2}$ adalah, "Jelaskan proses pembentukan keringat!". Pertanyaan ini merupakan pertanyaan konsep yang sudah dijelaskan dalam buku pembelajaran siswa.

Pertanyaan guru dan siswa yang paling sedikit muncul adalah pertanyaan kategori $\mathrm{C}_{3}$ (mengaplikasikan). Mengaplikasikan berkaitan erat dengan pengetahuan prosedural (Widodo, 2006). Contoh pertanyaan guru adalah' "Bagaimanakah langkah atau usaha kalian untuk menghindari pengeluaran keringat yang berlebih sehingga terhindar dari masalah kulit?". Contoh pertanyaan siswa adalah, "Apa yang membuktikan bahwa seseorang itu memakai narkoba melalui urin?". pertanyaanpertanyaan ini sangat berkaitan dengan bagaimana menjalankan dan menerapkan suatu proses.

Dilihat dari hasil penelitian, secara keseluruhan pertanyaan guru lebih banyak yang termasuk ke dalam kualitas HOTS, namun berbanding terbalik dengan pertanyaan guru, pertanyaan siswa secara keseluruhan lebih banyak yang termasuk ke dalam kualitas LOTS.

Mengajukan pertanyaan mendorong siswa untuk berpikir kritis. Selain itu keterampilan bertanya juga penting dalam pemecahan masalah dan mengambil keputusan (Pizzini dan Shepardson, 1991). Dari kasus tersebut sudah terlihat bahwa kemauan siswa untuk bertanya masih tergolong rendah, kalaupun ada siswa yang bertanya pertanyaan yang diajukan masih tergolong LOTS (Ramadhan dkk, 2017).

Pertanyaan bermutu atau berkualitas yang dikemukakan peserta didik dapat menunjukkan bahwa peserta didik telah melakukan proses berpikir dan bernalar. Kemampuan berpikir siswa yang rendah dapat berdampak pada hasil belajar kognitifnyaHasruddin (2009). Semakin banyak peserta didik yang mengajukan pertanyaan dengan kualitas yang baik, maka semakin banyak peserta didik yang melakukan proses berpikir (Amin dkk, 2017).

Banyaknya pertanyaan yang diajukan belum tentu menunjukkan kualitas pertanyaan yang baik. Permasalahan tersebut disebabkan oleh kurang baiknya pola interaksi antara guru dan siswa. Guru hanya melihat jumlah siswa yang bertanya dan tidak melihat kualitas pertanyaan yang diajukan oleh siswa. Mungkin guru berpikir bahwa semakin banyak siswa bertanya berarti semakin baik pula keterlibatan siswa dalam pembelajaran (Krishnan, 2009), padahal tidak semua pertanyaan dapat membuat siswa aktif dalam pembelajaran. Hal lain yang mempengaruhi adalah kurangnya pemberian umpan balik oleh guru kepada siswa (Ramadhan dkk, 2017). Sejalan dengan Fariha (2013) yang menyatakan bahwa salah satu faktor yang dapat mempengaruhi perkembangan kemampuan berpikir kritis adalah interaksi antara pengajar dan siswa. Siswa memerlukan suasana akademik yang memberikan kebebasan dan rasa aman bagi siswa untuk mengekspresikan pendapat dan 
keputusannya selama berpartisipasi dalam kegiatan pembelajaran (Zafri, 2012).

Melalui pengamatan penulis, ketiga guru yang mengajar di kelas memberikan tugas kepada siswa untuk dikerjakan di rumah, namun tugas tersebut diberikan pada saat materi pembelajaran selesai. Hal ini membuat siswa kurang mengetahui materi saat pembelajaran berlangsung karena tidak membahas materi di rumah. Padahal Sajidan dan Afandi (2017) mengatakan bahwa untuk dapat memberdayakan HOTS di kelas, peserta didik tidak boleh hanya memiliki pengetahuan dasar dan pemahaman konsep namun dapat menerapkan apa yang mereka pelajari. Pengajar perlu merangsang pemikiran kritis dalam proses berpikir mereka. Proyek dan tugas harus mencakup pertanyaan yang menantang siswa untuk mengklarifikasi pemahaman mereka, mengemukakan alasan dan bukti pemikiran mereka, menentukan sudut pandang dan perspektif mereka, menentukan implikasi dan konsekuensi, dan mengevaluasi konsep.

Salah satu alternatif peningkatan kemampuan berpikir siswa adalah dengan menggalakkan beragam pertanyaan yang memacu proses berpikir siswa. Pertanyaan adalah bunga api yang memicu proses berpikitr siswa dan salah satu kegunaan terpenting dari pertanyaan adalah untuk memacu keterampilan berpikir tinggi (Afcariono, 2008).

\section{KESIMPULAN}

Kuantitas pertanyaan guru biologi berdasarkan jumlah pertanyaan guru didapatkan bahwa lebih banyak pertanyaan secara lisan dibanding tulisan, yaitu $81 \%$ pertanyaan lisan dan $19 \%$ pertanyaan tulisan dari 59 pertanyaan guru, sedangkan kuantitas pertanyaan siswa lebih banyak pertanyaan tulisan dibanding lisan, yaitu sekitar 23\% pertanyaan secara lisan dan $77 \%$ pertanyaan secara tulisan dari 520 pertanyaan siswa.

Kualitas pertanyaan yang diukur berdasarkan taksonomi Bloom Revisi Anderson dan Krathwohl menunjukkan bahwa secara keseluruhan pertanyaan guru biologi di kelas XI MIA MAN 1 Medan tahun pembelajaran 2017/2018 lebih tinggi kualitas pertanyaan HOTS dibanding dengan kualitas pertanyaan LOTS. Kualitas pertanyaan HOTS sebesar $51 \%$ dan kualitas pertanyaan LOTS 49\%. Berbanding terbalik dengan kualitas pertanyaan guru biologi, kualitas pertanyaan siswa lebih tinggi kualitas pertanyaan LOTS dibanding HOTS.
Kualitas pertanyaan HOTS sebesar $69 \%$ dan kualitas pertanyaan LOTS 31\%

\section{DAFTAR PUSTAKA}

Afcariono, M., (2008), Penerapan Pembelajaran Berbasis Masalah untuk Meningkatkan Kemampuan Berpikir Siswa pada Mata Pelajaran Biologi, Jurnal Pendidikan Inovatif, 3(2): 65-68.

Amin, A.M., Aloysius D. C., Siti Z., dan Susriyati M., (2017), Identifikasi Kemampuan Bertanya dan Berpendapat Calon Guru Biologi pada Mata Kuliah Fisiologi Hewan, Bioedukasi, 15(1): 24-31.

Anderson, L.W. dan David R.K., (2010), Kerangka Pembelajaran, Pengajaran, dan Asesmen Revisi Taksonomi, Yogyakarta: Pustaka Pelajar.

Bulgar, S., Schorr, R.Y., and Maher, C.A, (2002), Teachers' Questions and Their Role in Helping Students Build an Understanding of Division of Fractions. In Cockburn, A.D. \& Nardi, E. (Eds). International Group for The Psychology of Mathematics Education: PME 26, University of East Angalia, 21-26 July. Norwich UK: Proceedings. 161-168.

Chin, C., dan Kayalvizhi G., (2002), Posing Problems for Open Investigations: What Questions Do Pupils Ask Research in Science \& Technological Education, 20(2): 269-287.

Chin, C., and Osberne, J., (2008), Students' Question: A PotentialResource For Teaching andLearning Science. Studies inScience Education. 44(1). 1-39.

Fariha, M., (2013). Kemampuan Berpikir Kritis Matematis dan Kecemasan Matematika dalam Pembelajaran dengan Pendekatan Problem Solving, Jurnal Peluang, 1(2): 43-50.

Hasibuan, J.J., (2008), Proses belajar mengajar . Bandung: PT. Remaja Rosdakarya.

Hasruddin, (2009), Memaksimalkan Kemampuan Berpikir Kritis Melalui Pendekatan Kontekstual, Jurnal Tabularasa PPS Unimed, 6(1): 48-60.

Hasruddin, (2011), Analisis Tipe Pertanyaan Siswa pada Penerapan Pembelajaran Kontekstual di Sekolah Menengah 
Pertama, Jurnal Dinamika Pendidikan, 4(3): 112-119.

Istiyono, E., Djemari Mardapi, dan Suparno, (2014),Pengembangan Tes Kemampuan Berpikir Tingkat Tinggi Fisika (PysTHOTS) Peserta Didik SMA, Jurnal Penelitian dan Evaluasi Pendidikan, 18(1): 1-12.

Krishnan, E.R., (2009), Teaching WithHEART: Using Questions as Partof Your Teaching Strategy; Encourge Students to Interact inClass. Bangkok Post Life, diakses tanggal 22 Juni 2018.

Mahanal, S., Pujiningrum, S.E., dan Suyanto, (2007), Penerapan Pembelajaran Berdasarkan Masalah dengan Strategi Kooperatif Model STAD pada Mata Pelajaran Sains untuk Meningkatkan Kemampuan Berpikir Kritis Siswa Kelas V MI Jenderal Sudirman Malang. Jurnal Penelitian Kependidikan, 17(1): 33-49.

Pizzini, E. L., \& Shepardson, D.P. (1991). Student questioning in the presence of the teacher during problem solving in science. Schoolscience and Mathematics, 9(1): 348-352.

Ramadhan F., Susriyati M. dan Siti Z., (2017), Kemampuan Bertanya Siswa Kelas $\mathrm{X}$ SMA Swasta Kota Batu pada Pelajaran Biologi, Bioedukasi, 8(1): 11-15.

Roestiyah, (2012), Strategi Belajar Mengajar, Jakarta, Rineka Cipta.

Sajidan dan Afandi, (2017), Pengembangan Model Pembelajaran IPA untuk Memberdayakan Keterampilan Berpikir Tingkat Tinggi, Prosiding Seminar Nasional Pendidikan Sains (SNPS) 2017: 15-27.

Sanjaya, W., (2005), Pembelajaran Dalam Implementasi Kurikulum BerbasisKompetensi, Jakarta, PT Fajar Interpratama.

Simamora, R., (2014), Buku Ajar Pendidikan dalam Keperawatan, Jakarta, EGC.

Smith, V. G., dan Szymanski A., (2013), Critical Thinking: More ThanTest Scores, National Council ofProfessors of EducationalAdministration (NCPEA), 8(2): 16-25.
Sudjana, N. dan Ibrahim, (1989), Penelitian dan Penilaian Pendidikan, Bandung, Sinar Baru.

Tanaya, I.N.T.B., Suciati, dan Maridi, (2017), Profil Kualitas dan Kuantitas Pertanyaan Siswa pada Pembelajaran Biologi Kelas XI MIA SMA Negeri 1 Madiun,Seminar Nasional Pendidikan Sains II UKSW 2017: 79-84.

Widodo, A., (2006), Taksonomi Bloom dan Pengembangan Butir Soal, Buletin Puspendik. 3(2): 18-29.

Yani, A. dan Bagja W., (2007), http://file.upi.edu/Direktori/FPIPS/JUR. _PEND.GEOGRAFI/197210242001121B AGJA_WALUYA/MEDIA_PEMBEL.GEOG RAFI/HO_Media_Pembelajaran_Geogr afi.pdf, diakses tanggal 18 Januari 2018.

Zafri, (2012). Berpikir Kritis Pembelajaran Sejarah, http://jurnaldiakronikafisunp. /2012/05/berpikir-kritis-pembelajaransejarah.html, diakses tanggal 22 juni 2018. 